\title{
Kombinasjonsbehandling ved depresjon
}

\author{
I de tilfellene der monoterapi med et antidepressivt legemiddel ikke gir \\ tilfredsstillende effekt, kan kombinasjonsbehandling vurderes. Årsaker \\ til terapisvikt, som feil diagnose eller ikke-optimalt valg av legemiddel \\ og/eller dosering, bør først ekskluderes.
}

Se også kunnskapsprøve på www.tidsskriftet.no/quiz

\author{
Gudrun Høiseth \\ gudrun.hoiseth@diakonsyk.no \\ Dag Kristen Solberg \\ Helge Refsum \\ Senter for psykofarmakologi \\ Diakonhjemmet Sykehus
}

Depresjon er en svært vanlig sykdom - med en livstidsprevalens på $10 \%$ for menn og $24 \%$ for kvinner, i henhold til en norsk studie (1). Et legemiddel fra gruppen antidepressiver forskrives til en stor del av disse pasientene, men det er tilfredsstillende effekt hos under $50 \%$ (2). Et alternativ kan være å forsøke kombinasjonsbehandling med flere legemidler. Vi vil i denne artikkelen presentere aspekter ved slik behandling.

Grunnlaget for artikkelen er et litteratursøk i PubMed. Det ble gjort et skjønnsmessig utvalg av artikler ut fra forfatternes erfaring fra psykiatri og farmakologi.

\section{Forskjellige typer antidepressiver}

Tabell 1 gir en oversikt over de antidepressivene som selges i Norge (3). De første legemidlene mot depresjon kom på markedet $\mathrm{i}$ 1950-årene og tilhørte gruppen trisykliske antidepressiver (TCA). De hemmer reopptak av noradrenalin og serotonin, men har også en del andre effekter, blant annet antikolinerge bivirkninger. Trisykliske antidepressiver har en relativt høy toksisitet som ikke er til stede hos de nyere selektive serotoninreopptakshemmerne (SSRI), serotonin-noradrenalinreopptakshemmere eller selektive noradrenalin- og noradrenalin-dopamin-reopptakshemmere. På grunn av få andre effekter enn hemming av monoaminreopptaket er disse nyere legemidlene også antatt å ha mindre bivirkninger.

En annen gruppe legemidler med antidepressiv virkning er reseptorantagonistene, som blokkerer de hemmende presynaptiske alfa-2-reseptorene, først og fremst på noradrenerge, men også noe på serotonerge nevroner. I tillegg finnes gruppen reversible monoaminoksidasehemmere, som hemmer nedbrytningen av monoaminer.

\section{Årsaker til terapisvikt ved bruk av antidepressiver}

Et betydelig antall studier utført over flere tiår har vist at antidepressiver har bedre effekt enn placebo ved depresjon. Det er flere faktorer som må tas med i vurderingen før man kan overføre dette til klinisk praksis. For det første er det vist at det er en publikasjonsskjevhet, slik at det nærmest utelukkende er de studiene som viser effekt som er blitt publisert (4). For det andre er de kliniske studiene utført på mer alvorlig deprimerte pasienter enn de pasientene som ofte får antidepressiver i klinisk praksis. Det er vist at legemidlene har best effekt på dem med de alvorligste symptomene, og det er ikke entydig vist at antidepressive legemidler er mer effektive enn placebo i behandlingen av mild depresjon (5). Hos pasienter med mild til moderat depresjon vil effekten av antidepressiv behandling derfor ofte være dårligere enn det lege og pasient forventer.

Feil diagnose vil gi terapisvikt. Antidepressive legemidler er forventet å fungere best på primære endogene depresjoner og dårligere på depresjoner som er sekundære til somatisk sykdom (6). Dersom den aktuelle depresjonen er et ledd i en bipolar lidelse, har antidepressiver også dårligere forventet effekt (6).

Sviktende etterlevelse er en annen hyppig årsak til at ønsket effekt ikke oppnås. Det er viktig at riktig legemiddel brukes i riktig dose over lang nok tid. Lav serumkonsentrasjon som skyldes dårlig etterlevelse kan påvises med serumkonsentrasjonsmålinger. Genetisk avvikende legemiddelmetabolisme forekommer hos en liten del av befolkningen. Dette kan påvises ved farmakogenetisk analyse.

\section{Kombinasjonsbehandling}

Når andre årsaker til terapisvikt er utelukket, vil ofte førstevalget være å skifte til et annet legemiddel innen gruppen antidepressiver (2,
7). Vi har ikke funnet dokumentasjon for at økning utover anbefalte doser er effektivt. Det er vist liten forskjell mellom de ulike antidepressivene når det gjelder langtidseffekt, men trisykliske antidepressiver er vist å ha noe bedre effekt enn SSRI-preparater ved alvorlig depresjon. Mye av denne forskjellen vil bli mindre grunnet dårligere etterlevelse som følge av at trisykliske antidepressiver gir mer plagsomme bivirkninger (2).

\section{Legemiddel fra annen medikamentgruppe}

Et annet alternativ ved terapisvikt er kombinasjon av et antidepressiv med et legemiddel fra en annen medikamentgruppe. I flere studier er det vist at litium eller thyreoideahormonet $\mathrm{T}_{3}$ har god effekt som tilleggsbehandling, men særlig er det vist effekt sammen med trisykliske antidepressiver (7). Potensielle bivirkninger og mangel på dokumentasjon for effekt sammen med nyere antidepressiver fører til at kombinasjoner med litium og thyreoidahormonet $\mathrm{T}_{3}$ er lite populære (8).

Kombinasjon av et SSRI-middel med et stemningsstabiliserende legemiddel, for eksempel lamotrigin, er i enkelte studier vist å ha effekt (9). Denne effekten kan delvis skyldes at depresjonen hos noen pasienter egentlig er ledd i en bipolar lidelse. Store industrisponsede, placebokontrollerte studier er gjort av annengenerasjons antipsykotika som tilleggsbehandling til SSRI-preparater eller serotonin-noradrenalin-reopptakshemmere. Flere antipsykotika, blant annet quetiapin og aripiprazol, har vist effekt i disse studiene (7). Ved slike kombinasjoner må risikoen for ekstrapyramidale og metabolske

\section{Hovedbudskap}

- Ved manglende effekt av antidepressiv behandling bør årsaker som feil diagnose, lav dosering, dårlig etterlevelse og preparatvalg vurderes

- Dersom kombinasjonsbehandling med to antidepressiver vurderes, bør forskjellig virkningsprofil benyttes, f.eks. tillegg av reseptorblokkeren mirtazapin eller mianserin til en selektiv serotoninreopptakshemmer

- Dokumentasjonen for effekt av kombinasjonsbehandling med antidepressiver er begrenset, men bruken er likevel utbredt 
bivirkninger vurderes opp mot nytten av behandlingen (7).

Det er også vist at psykoterapi, for eksempel kognitiv terapi, har tilleggseffekt når dette kombineres med antidepressiver (10). Slik tilleggseffekt er også vist for omega-3fettsyren eikosapentaensyre (EPA) (11).

\section{Kombinasjon av to antidepressiver}

Et annet alternativ er å kombinere to legemidler innen gruppen antidepressiver. Teoretisk vil det å kombinere to legemidler med forskjellig virkningsprofil gi bedre effekt. For eksempel kan man legge til noradrenerg virkning hos en pasient som står på et mer rent serotonergt medikament. Det er likevel begrenset dokumentasjon for at kombinasjon av to legemidler innen gruppen antidepressiver er mer effektivt enn behandling med ett medikament alene. Flest studier er gjort på kombinasjonsbehandling med en selektiv serotoninreopptakshemmer og reseptorblokkerne mirtazapin eller mianserin. De fleste studier er designet slik at kombinasjonsterapi blir gitt til pasienter som har hatt terapisvikt ved bruk av ett antidepressivt legemiddel.

I tre kontrollerte, randomiserte studier er det vist bedre effekt av kombinasjonen selektive serotoninreopptakshemmere og mirtazapin enn av hvert av legemidlene alene (7). I en av disse studiene var det en placebogruppe, og der ble det vist at kombinasjonsterapi var mer effektivt enn tillegg av placebo (2). En kontrollert studie med 105 pasienter viste bedre effekt av kombinasjonen venlafaksin og mirtazapin sammenliknet med fluoksetin alene. Behandlingsalternativene ble gitt fra behandlingsstart, ikke etter terapisvikt $(2,7)$. I en nyere studie med 665 pasienter fant man derimot ikke bedre effekt av kombinasjonen venlafaksin og mirtazapin enn av escitalopram alene (12).

I to kontrollerte studier er det vist bedre effekt av behandling med mianserin og fluoksetin enn av fluoksetin alene (6). I en av disse studiene ble tillegg av placebo gitt til den gruppen som kun fikk fluoksetin (6). I en tredje studie med 1629 pasienter som ikke hadde respondert på seks ukers sertralinbehandling, var det ikke bedre resultater ved tillegg av mianserin sammenliknet med det å fortsette med sertralin alene (6).

Det noradrenerge og dopaminerge antidepressive legemidlet bupropion er nylig lansert i Norge. I en studie der amerikanske psykiatere ble spurt om hvilket preparat de ville foretrekke å legge til hos en pasient som ikke hadde hatt effekt av behandling med selektive serotoninreopptakshemmere, svarte $30 \%$ bupropion. Dokumentasjonen for effekt av slik kombinasjon virker lovende, men det er fremdeles ikke utført store placebokontrollerte studier (13).

Tillegg av trisykliske antidepressiver til fluoksetin ble studert i en dobbeltblind, kontrollert studie der 41 pasienter som ikke hadde respondert på fluoksetinbehandling, ble ran-

Tabell 1 Oversikt over legemidler innen de forskjellige gruppene antidepressiver solgt i Norge (3)

\section{Gruppe}

Trisykliske antidepressiver (TCA)

Selektive serotoninreopptakshemmere (SSRI)

Selektive noradrenalin-serotonin-reopptakshemmere (SNRI)

Selektive noradrenalinreopptakshemmere

Reseptorblokkere

Reversible monoaminoksidasehemmere

Noradrenalin-dopamin-reopptakshemmere
Legemidler

Amitryptilin, doksepin, klomipramin nortriptylin, trimipramin

Citalopram, escitalopram, fluoksetin, fluvoksamin, paroksetin, sertralin

Duloksetin, venlafaksin

Reboksetin

Mianserin, mirtazapin

Moklobemid

Bupropion domisert til økt dose fluoksetin eller tillegg av desipramin (et trisyklisk antidepressiv som ikke er registrert i Norge). Økning av fluoksetindosen ga signifikant bedre resultater enn tillegg av desipramin (8). Det finnes en annen studie, der 38 pasienter ble randomisert til behandling med fluoksetin, desipramin eller en kombinasjon av disse to fra behandlingsstart. Dosen av fluoksetin var da lik $(20 \mathrm{mg}) \mathrm{i}$ begge gruppene. I denne studien var det signifikant bedre effekt av kombinasjonsterapi enn av et av legemidlene gitt alene (7). I henhold til dokumentasjonen kan det derfor virke som det er begrenset effekt av å kombinere trisykliske antidepressiver og selektive serotoninreopptakshemmerne i antidepressiv behandling.

\section{Interaksjoner og bivirkninger}

Ved kombinasjon av antidepressiver er det særlig to forhold som er viktige for å unngå komplikasjoner. For det første øker risikoen for serotonergt syndrom og andre farmakodynamiske interaksjoner når forskjellige virkningsmekanismer kombineres. Dette gjelder ved alle kombinasjoner innen gruppen antidepressiver, men kombinasjon av selektive serotoninreopptakshemmere eller trisykliske antidepressiver med monoaminoksidasehemmere er spesielt risikabel.

Muligheten for bivirkninger vil også øke, og $i$ en studie fant man at flere av dem som fikk kombinasjonsbehandling med citalopram og et annet antidepressiv avsluttet enn av dem som sto på citalopram alene (14). I de fleste andre kombinasjonsstudier har man derimot funnet at behandlingen er godt tolerert (2). For det andre kan farmakokinetiske interaksjoner ytterligere forsterke de farmakodynamiske interaksjonene. For eksempel vil de selektive serotoninreopptakshemmerne fluoksetin og paroksetin hemme CYP 2D6-metabolismen av flere trisykliske antidepressiver (amitryptilin, nortryptilin og trimipramin), slik at dosen trisykliske antidepressiver må reduseres.

\section{Praksis}

En australsk studie viste at $79 \%$ av psykiaterne i løpet av sin karriere hadde forskrevet kombinasjonsbehandling med to antidepressiver, oftest kombinasjonen selektive serotoninreopptakshemmere og trisykliske antidepressiver eller mirtazapin. Tilsvarende tall er funnet i USA (15). Dette viser at kombinasjonsterapi med antidepressiver er utbredt, på tross av at det finnes få store placebokontrollerte studier som viser at slik behandling er mer effektiv enn monoterapi.

\section{Konklusjon}

Selv om førstevalget ved terapisvikt ved bruk av antidepressiver er å skifte til et annet legemiddel, kan kombinasjonsbehandling være et alternativ når flere forsøk med monoterapi ikke gir tilfredsstillende effekt. Årsaker som feil diagnose, dårlig etterlevelse og ikke-optimalt valg av legemiddel og/eller dosering bør først utelukkes. Innen gruppen antidepressiver er det få kombinasjoner som har vist effekt i store placebokontrollerte studier. Enkelte kontrollerte studier har imidlertid vist noen lovende resultater, og kombinasjonsbehandling kan vurderes ved behandlingsresistent depresjon.

\section{Gudrun Høiseth (f. 1976)}

er lege i spesialisering i klinisk farmakologi. Hun har en doktorgrad i alkoholmetabolisme. Forfatter har fylt ut ICMJE-skjemaet og oppgir ingen interessekonflikter.

\section{Dag Kristen Solberg (f. 1968)}

er spesialist i psykiatri og i klinisk farmakologi. Forfatter har fylt ut ICMJE-skjemaet og oppgir ingen interessekonflikter.

\section{Helge Refsum (f. 1947)}

er professor dr.med. og spesialist i klinisk farmakologi. Han er avdelingsoverlege og leder av Senter for psykofarmakologi ved Diakonhjemmet Sykehus.

Forfatter har fylt ut ICMJE-skjemaet og oppgir ingen interessekonflikter. 


\section{Litteratur}

1. Kringlen E, Torgersen S, Cramer V. A Norwegian psychiatric epidemiological study. Am J Psychiatry 2001; 158: 1091-8.

2. Kennedy SH, Young AH, Blier P. Strategies to achieve clinical effectiveness: refining existing therapies and pursuing emerging targets. J Affect Disord 2011; 132 (suppl 1): S21-8.

3. Norsk legemiddelhåndbok.

http://legemiddelhandboka.no/Legemidler/53280 (18.3.2012).

4. Turner EH, Matthews AM, Linardatos E et al. Selective publication of antidepressant trials and its influence on apparent efficacy. N Engl J Med 2008; 358: 252-60

5. Fournier JC, DeRubeis RJ, Hollon SD et al. Antidepressant drug effects and depression severity: a patient-level meta-analysis. JAMA 2010; 303: 47-53.

6. Keks NA, Burrows GD, Copolov DL et al. Beyond the evidence: is there a place for antidepressant combinations in the pharmacotherapy of depression? Med J Aust 2007: 186: 142-4.

7. Connolly KR, Thase ME. If at first you don't succeed: a review of the evidence for antidepressant augmentation, combination and switching strategies. Drugs 2011; 71: 43-64.

8. Fava M. Augmentation and combination strategies in treatment-resistant depression. J Clin Psychiatry 2001; 62 (suppl 18): 4-11.

9. Barbosa L, Berk M, Vorster M. A double-blind, randomized, placebo-controlled trial of augmentation with lamotrigine or placebo in patients concomitantly treated with fluoxetine for resistant major depressive episodes. J Clin Psychiatry 2003; 64: 403-7.

10. Cuijpers P, Clignet F, van Meijel B et al. Psychological treatment of depression in inpatients: a systematic review and meta-analysis. Clin Psychol Rev 2011; 31: 353-60.

11. Martins JG. EPA but not DHA appears to be responsible for the efficacy of omega-3 long chain polyunsaturated fatty acid supplementation in depression: evidence from a meta-analysis of randomized controlled trials. J Am Coll Nutr 2009; 28 $525-42$.

12. Rush AJ, Trivedi MH, Stewart JW et al. Combining medications to enhance depression outcomes (CO-MED): acute and long-term outcomes of a single-blind randomized study. Am J Psychiatry 2011: 168: 689-701.

13. Zisook S, Rush AJ, Haight BR et al. Use of bupropion in combination with serotonin reuptake inhibitors. Biol Psychiatry 2006; 59: 203-10.

14. Sanglier T, Milea D, Saragoussi D et al. Increasing escitalopram dose is associated with fewer discontinuations than switch or combination approaches in patients initially on escitalopram 10mg. Eur Psychiatry 2010; 25: e-publisert 30.10.

15. Horgan D. Dodd S. Combination antidepressants use by GPs and psychiatrists. Aust Fam Physician 2011; 40: 397-400.

Mottatt 28.10. 2011, første revisjon innsendt 4.1. 2012, godkjent 22.3. 2012. Medisinsk redaktør Mette Sagsveen. 